\title{
THE IBN EZRA-HENRY BATE ASTROLOGICAL CONNECTION AND THE THREE ABRAHAMS
}

\author{
SHLOMO SELA \\ BAR-ILAN UNIVERSITY
}

\begin{abstract}
This paper studies the astrological connection between Abraham Ibn Ezra (ca. 1089-ca. 1161), who created the first comprehensive corpus of Hebrew astrological textbooks that address the main systems of Arabic astrology, and Henry Bate (1246-1310), who first translated into Latin a collection of Ibn Ezra's astrological writings and brought Ibn Ezra to the knowledge of the Latin West. The first part of this paper offers a brief chronological survey of how Henry Bate became acquainted with Ibn Ezra's astrological treatises. The second part focuses on a surprising element: when Bate refers to astrological treatises that we now know were written by Ibn Ezra, he assigns them to one of three different authors. All three are 'Abraham', but they have distinguishing cognomens. Here we determine which astrological treatises Bate assigned to each of the three Abrahams, try to identify the historical figure behind each of them, and explain Bate's reason for trisecting Abraham Ibn Ezra.
\end{abstract}

Key Words

Hebrew astrology, Latin astrology, Latin translations, Old French translations.

The bulk of the literary career of Abraham Ibn Ezra (ca. 1089-ca. 1161) played out in the Latin West. Born in Muslim Spain, he left his homeland at the age of 50 and began a nomadic itinerant life through Italy, France, and England, during which he wrote prolifically on a wide variety of subjects. His reputation rests on his outstanding biblical commentaries, but his intellectual interests extended to the 
sciences, ${ }^{1}$ especially astrology. Ibn Ezra's most significant contribution in this field is the creation of the first comprehensive corpus of Hebrew astrological textbooks that address the main systems of Arabic astrology. Today we know of nineteen treatises by him. ${ }^{2}$ This relatively large number reflects the multiple versions or recensions of each individual work that he produced. This phenomenon is typical of his literary career: he would set down a new version of an old work for a new patron when he arrived in a new town, thereby continuing to stimulate the attention and curiosity of readers all along his itinerary through Latin Europe.

There are strong indications that Ibn Ezra had direct relations with Christian scholars during his peregrinations through Latin Europe, and that some of his works became known to Christian scholars shortly after his death and were then translated or elaborated for Latin readers. This is supported by codicological evidence: most of the Latin works ascribed to Ibn Ezra, supposed to have been written with his participation, or based on material derived from his work survive in manuscripts from the twelfth century. ${ }^{3}$ It seems, though, that Ibn Ezra never went beyond sporadic contacts with Christian scholars. In contrast to the quick diffusion of his Hebrew astrological work among Jews, ${ }^{4}$ and the transmission of Arabic astrological literature to Christian readers via Latin translations, ${ }^{5}$ Ibn Ezra's astrological writings remained outside the mainstream of

1 For a chronological listing of Ibn Ezra's scholarly writings and the stations along his wanderings, bibliographical references to Ibn Ezra's oeuvre, and secondary literature on his work, see Shlomo Sela and Gad Freudenthal, 'Abraham Ibn Ezra's Scholarly Writings: A Chronological Listing', Aleph 6 (2006), pp. 13-55.

2 For a list of these astrological treatises, sorted according to the main genres of Greek and Arabic astrological literature to which they belong, and accompanied by references to editions in which these treatises are available today, see Abraham Ibn Ezra's Introductions to Astrology, A Parallel Hebrew-English Critical Edition of the Book of the Beginning of Wisdom and the Book of the Judgments of the Zodiacal Signs, Edited, translated, and annotated by Shlomo Sela, Leiden: Brill, 2017, pp. 2-5.

3 Tony Lévy and Charles Burnett, 'Sefer ha-Middot: A Mid-Twelfth-Century Text on Arithmetic and Geometry Attributed to Abraham ibn Ezra', Aleph 6 (2006), pp. 57-238; Renate Smithuis, 'Science in Normandy and England under the Angevins. The Creation of Avraham Ibn Ezra's Latin Works of Astronomy and Astrology', in G. Busi, ed., Hebrew to Latin-Latin to Hebrew: The Mirroring of Two Cultures in the Age of Humanism, Turin: Aragno, 2006, pp. 26-61; José M. Millás Vallicrosa, ed., El Libro de los Fundamentos de las Tablas Astronómicas de R. Abraham Ibn Ezra, Madrid-Barcelona: CSIC, 1947; José M. Millás Vallicrosa, 'Un nuevo tratado de astrolabio de R. Abraham ibn Ezra', AlAndalus, 5 (1940), pp. 9-29. See also Charles Burnett, 'Béziers as an Astronomical Centre for Jews and Christians in the Mid-Twelfth Century', Aleph, forthcoming.

4 Shlomo Sela, 'Astrology in Medieval Jewish Thought', in G. Freudenthal, (ed.) Science in Medieval Jewish Cultures, Cambridge: Cambridge University Press, 2012, pp. 296-299; idem, 'The Astrological-Astronomical Encyclopedia in MS Paris 1058', Aleph 14.1 (2014), pp. 189-241.

5 David Juste, 'The Impact of Arabic Sources on European Astrology: Some Facts and Numbers', Micrologus XXIV (2016), pp. 173-194; Jean-Patrice Boudet, Entre science et nigromance. Astrologie, 
The Ibn Ezra-Henry Bate Astrological Connection and the Three Abrahams

Latin astrological literature until the last decades of the thirteenth century. This emerges from the fact that neither Ibn Ezra's name nor references to any of his works are found in the exhaustive catalogue of astrological writings in the Speculum astronomiae (Mirror of astronomy), possibly composed sometime after 1260 by Albertus Magnus, ${ }^{6}$ and so too in the Liber astronomicus, the most important astrological work of the thirteenth century, composed by Guido Bonatti around $1270 .^{7}$ But then, Ibn Ezra was 'reborn' in the Latin West thanks to two almost simultaneous translation projects carried out in the last decades of the thirteenth century.

Why did the Latin West wait more than a century after Ibn Ezra's death to discover his astrological enterprise? In the wake of the translation of Arabic astrological texts into Latin and the introduction of Aristotelian texts on natural philosophy during the twelfth and particularly the thirteenth centuries, the consequent integration of astrology in medical treatment, the employment of astrologers to advise the European nobility, and the huge increase in the number of university graduates in medieval Europe, astrology emerged as a fascinating topic of study and a unifying theory of knowledge, on the one hand, and as a more visible target for those who viewed it with suspicion, on the other. The conflict broke out in Paris with the condemnations of 1270 and 1277, on the eve of the translations of Ibn Ezra's astrological writings. ${ }^{8}$ It was in Paris, in the last decades the thirteenth century, that Henry Bate and Peter d'Abano, the two translators who brought Ibn Ezra to the knowledge of the Latin West, pursued their academic careers, one as a student in theology and the arts, the other as a professor of medicine.

divination et magie dans l'Occident médiéval (XIIe -XVe siècle), Paris: Publications de la Sorbonne, 2006, pp. 35-82; see below, notes 6 and 7 .

6 Paola Zambelli, The Speculum Astronomiae and Its Enigma, Dordrecht: Kluwer Academic Publishers, 1992, pp. 208-273.

7 Guidonis Bonati Forolviensis Mathematici de Astronomia Tractatus X, Basileae, 1550; Lynn Thorndike, A History of Magic and Experimental Science, New York: Columbia University Press, 1923-1958, vol. II, ch. 67, pp. 825-835, esp. pp. 826-827.

8 See Zambelli, The Speculum Astronomiae and Its Enigma, pp. 3-23, 45-125; Agostino Paravicini Bagliani, Le 'Speculum Astronomiae', une énigme? Enquête sur les manuscrits, Firenze: SISMEL Edizioni del Galluzzo, 2001; Boudet, Entre science et nigromance, pp. 251-258; Scott Hendrix, How Albert the Great's Speculum Astronomiae Was interpreted and Used by Four Centuries of Readers: A Study in Late Medieval Medicine, Astronomy and Astrology, Lewiston: The Edwin Mellen Press, 2010, pp. 33-51; Nancy G. Siraisi, Medieval \& Early Renaissance Medicine: An Introduction to Knowledge and Practice, Chicago and London: The University of Chicago Press, 1990, pp. 67-68; Edward Grant, The Foundations of Modern Science in the Middle Ages, Cambridge: Cambridge University Press, 1996, pp. 37-38. 


\section{Part One \\ Henry Bate's Acquaintance with Abraham Ibn Ezra's Astrological Corpus}

Here I am concerned with Henry Bate, whose translation endeavors slightly preceded those of Peter d'Abano. The next-to-last child of a large family, Henry Bate was born on March 24, 1246, in Malines (Mechelen). He studied in Paris, probably under Albertus Magnus, and became proficient in astronomy, astrology and philosophy, and earned recognition as a master of arts before 1274. The most important of Bate's works is the Speculum divinorum et quorumdam naturalium (Mirror of the divine substances and some natural things), a philosophic and scientific encyclopedia composed between 1301 and 1305 and dedicated to Guy de Hainaut, Henry Bate's patron. He died sometime after January $1310 .{ }^{9}$

Four main stages may be discerned in the development of the Henry BateAbraham Ibn Ezra connection, as follows. In 1273, when Henry Bate was a student at the University of Paris and well before the composition of his first known book, ${ }^{10}$ he commissioned a Jewish scholar named Hagin le Juif to translate a collection of Ibn Ezra's astrological works from Hebrew into Old French. Preserved in two manuscripts, this collection includes the following four items: (1) Li livres du commencement de sapience, (2) Livre des jugemens des nativités, (3) Le livre des elections Abraham, and (4) Le livre des interrogations. ${ }^{11}$ These are Old French translations of respectively (1) Reshit Hokhmah (Beginning of wisdom), an introduction to astrology that is considered to be the zenith of Ibn Ezra's astrological work:;2 (2) Sefer ha-Moladot (Book of nativities; henceforth Moladot), Ibn Ezra's only extant complete text in Hebrew on the astrological doctrine of nativities, ${ }^{13}$ (3) the second version of Sefer ha-Mivharim (Book of elections;

9 Aleksander Birkenmajer, 'Henri Bate de Malines, astronome et philosophe du XIIIe siècle' (1923), reprinted in Idem, Etudes d'histoire des sciences et de la philosophie du Moyen Age, Krakow: Ossolineum, 1970, pp. 105-115; Gaston Wallerand, Henri Bate de Malines, Speculum Divinorum et Quorundam Naturalium, Louvain: Institut Supérieur de Philosophie de l'Université, 1931, pp. 723; Emmanuel Poulle, 'Henry Bate of Malines' in Dictionary of Scientific Biography, vol. VI, New York, 1972, pp. 272-275.

10 Gaston Wallerand, Henri Bate de Malines, p. 11.

11 Bibliothèque nationale de France, fonds français, 24276, fols. 1a-66a, and Bibliothèque nationale de France, fonds français, 1351, fols. 1a-66a.

12 This introduction to astrology is divided into 10 chapters and extant in no fewer than 70 manuscript copies. References to this work are in the format: Reshit Hokhmah, ed. Sela, §2.2:1, pp. 64-65 = Reshit Hokhmah, chapter 2, section 2, passage 1 in Abraham Ibn Ezra's Introductions to Astrology, ed. Sela, on pp. 64-65.

13 References to Moladot, which is extant in at least 53 manuscript copies, are in the format: Moladot, ed. Sela, III vi 8, 4, pp. 152-153 = Moladot, part III ('The Twelve horoscopic Places') chapter 6 (addressing the sixth horoscopic place), section 8, sentence 4, in Abraham Ibn Ezra on Nativities and Continuous Horoscopy, A Parallel Hebrew English Critical Edition of the Book of Nativities and the Book of Revolution, Edited, translated, and annotated by Shlomo Sela, Leiden: Brill, 2013, pp. 152-153. 
The Ibn Ezra-Henry Bate Astrological Connection and the Three Abrahams

henceforth Mivharim II), on choosing the most auspicious moment for performing specific actions, ${ }^{14}$ and (4) the second version of Sefer ha-She elot (Book of interrogations; henceforth She 'elot II), on replying to questions addressed to the astrologer. ${ }^{15}$ We have substantial bibliographical information only on the first item, from whose colophon we learn that the Hebrew original of Li livres du commencement de sapience was composed by Abraham Ibn Ezra, translated by Hagin le Juif from Hebrew into Old French, and written down in Old French by a certain Obers de Mondidier in Henry Bate's house in Malines at the end of 1273. ${ }^{16}$

In 1280, Henry Bate composed an astrological autobiography, entitled Liber Servi Dei de Mechlinia de Ducatu Brabantie super inquisitione et verificatione nativitatis incerte ex iudiciis ac subsequentibus nato post nativitatem (Book by a servant of God from Malines in the Duchy of Brabant, on the determination and verification of an uncertain nativity on the basis of judgments and subsequent <events occurring to> the native after <his> birth; henceforth Nativitas). ${ }^{17}$ To anchor the astrological interpretation of his own life, Bate incorporated many astrological texts, including at least 140 paraphrases, translations, and quotations from twelve astrological treatises written by or attributed to Abraham Ibn Ezra. These references (whose correspondences with Ibn Ezra's astrological corpus will be studied below) are the first known in the Latin West. That seven years elapsed between 1273 and the composition of Nativitas shows that Henry Bate commissioned Hagin le Juif so that Bate could have an initial look at Ibn Ezra's astrological work rather than to translate it into Latin.

Bate's first translation of Ibn Ezra was De mundo vel seculo, a Latin rendering of the first version of Sefer ha- 'Olam (Book of the World, henceforth 'Olam I), on historical and meteorological astrology. ${ }^{18}$ This translation, equipped with a

14 References to Mivharim II, which is extant in 28 manuscript copies, are in the format: Mivharim II, §7.1:6, pp. 164-165 = second version of Sefer ha-Mivharim, chapter 7, section 1, sentence 6, in Abraham Ibn Ezra on Elections, Interrogations and Medical Astrology, ed. Sela, pp. 164-165.

15 References to She 'elot II, which is extant in 35 manuscript copies, are in the format: She 'elot II, \$7.1:2, pp. 368-369 = second version of Sefer ha-She elot, chapter 7, section 1, sentence 2, in Abraham Ibn Ezra on Elections, Interrogations and Medical Astrology, A Parallel Hebrew English Critical Edition of the Book of Elections ( 3 Versions), the Book of Interrogations (3 versions) and the Book of the Luminaries, Edited, translated, and annotated by Shlomo Sela, Leiden: Brill, 2011, pp. 368-369.

16 Paris, Bibliothèque nationale de France, Français 24276, fol. 66b: 'Ci define li livers de Commencement de Sapience que fist Abraham Even Aze ou Aezera qui est interpretes maistre de aide que translata Hagins li Juis de ebrieu en romans et Obers de Mondidier escriboit le romans et du fait a Malines en la meson sire Henri Bate et fu fines l'en de grace 1273'.

17 References to this work are in the format: Nativitas, ed. Steel, lines 572-573 = A Medieval Autobiographical Horoscope: Henry Bate's Nativitas (1280), edited by Carlos Steel, annotated and introduced by Steven Vandenbroecke, with the collaboration of David Juste and Shlomo Sela, Leuven: Leuven University Press, 2017, lines 572-573.

18 References to 'Olam I, which is extant in 26 manuscript copies, are in the format: 'Olam I, ed. Sela, $\S 45: 1$, pp. $82-83$ = first version of Sefer ha-' Olam, section 45 , sentence 1, in The Book of the 
prologue by Henry Bate himself, had a wide diffusion: it survives in at least 19 manuscripts ${ }^{19}$ and a print edition. ${ }^{20}$ From the colophon of the earliest extant manuscript and the print edition we learn that this translation, was begun in Liege and completed in Malines in $1281 .^{21}$

In 1292, eleven years after the first translation and nineteen years after Hagin le Juif's Old French translations, Bate produced five more Latin translations of astrological treatises by Ibn Ezra in Orvieto, during his stay there with his patron, Guy de Hainaut, as follows: (1) Introductorius ad astronomiam, a translation of Reshit Hokhmah, was completed on August 22,1292, and is extant in four manuscripts. ${ }^{22}$ This is the only one of Bate's six Latin translations of Ibn Ezra astrological treatises that corresponds to one of Hagin's four Old French translations. (2) De luminaribus seu de diebus creticis is a translation of Sefer ha-Me'orot (Book of the luminaries; henceforth $M e^{\prime}$ 'orot), which deals with the critical days when there are marked changes in the symptoms of a disease. ${ }^{23}$ This translation, dedicated to the bishop of Aversa, is extant in three manuscripts and a print edition as well. ${ }^{24}$ (3) Liber introductionis ad iudicia astrologie is Mishpetei ha-Mazzalot (Judgments of the zodiacal signs), Ibn Ezra's second introduction to astrology. ${ }^{25}$ This translation is

World, A Parallel Hebrew-English Critical Edition of the Two Versions of the Text, Edited, translated, and annotated by Shlomo Sela, Leiden-Boston: Brill Academic Publishers, 2010, pp. 82-83.

19 For a list of the manuscripts, see Gaston Wallerand, Henri Bate de Malines, Speculum Divinorum et Quorundam Naturalium, Louvain: Institut Supérieur de Philosophie de l'Université, 1931, pp. 1516.

20 Abrahe Avenaris Iudei Astrologi peritissimi in re iudiciali opera, Venice: Petrus Liechtenstein, 1507, sig. LXXVIIv2-LXXXVr1. For the prologue written by Henry Bate himself, see sig. LXXVIr1LXXVIIV2.

21 Oxford, Bodleian, Digby 212, fol. 52v2: 'Explicit liber de Mundo vel seculo completus die lune post festum beati Luce hora diei quarta et anno domini 1281 inceptus de Leodio perfectus in Machlinia translatus a magistro Henrico Bate de hebreo in latinum'; cf. Abrahe Avenaris Iudei Astrologi peritissimi in re iudiciali opera, Venice: Petrus Liechtenstein, 1507, sig. LXXXV.

22 Leipzig Univ. 1466, fols. 2r-23v; Berlin 963, fols. 152-163r; Wolfenbütel, 2816, fols. 84-111; Vatican, Palat. lat. 1377, fols. 21r-37v; cf. Wallerand, Henri Bate, 17; Lynn Thorndike, 'The Latin translations of the astrological tracts of Abraham Avenezra', Isis 35 (1944), pp. 293-302, esp. p. 296 (a).

23 References to $\mathrm{Me}$ ' orot, which is extant in 35 manuscript copies, are in the format: $M e^{\prime}$ orot, ed. Sela, \$25:4, pp. 472-473 = Sefer ha-Me' orot, section 25, passage 4 in Abraham Ibn Ezra on Elections, Interrogations and Medical Astrology, ed. Sela, pp. 472-473.

24 Leipzig Univ. 1466, fols. 30v-34r; MS Limoges 9(28), fols. 66-71v; MS Prague 433 (III.C.2), fol. 118v2-125r2; Abraham Ibn Ezra: De luminaribus et diebus criticis, Padua: Matthaeus Cerdonis, 7 Feb. 1482/83; cf. Wallerand, Henri Bate, 17; Thorndike, 'The Latin Translations', 300 (a).

25 This introduction to astrology, which is extant in at least 25 manuscript copies, is quite different in its size and organization from Reshit Hokhmah, and. References to Mishpetei haMazzalot, which is extant in 35 manuscript copies, are in the format: Mishpetei ha-Mazzalot, ed. Sela, §29:1, pp. 512-513 = Mishpetei ha-Mazzalot, section 29, passage 1 in: Abraham Ibn Ezra's Introductions to Astrology, ed. Sela, pp. 512-513. For a critical edition of Mishpetei ha-Mazzalot, see Abraham Ibn Ezra's Introductions to Astrology, ed. Sela, pp. 488-555. 
extant in two manuscripts. According to the colophon of one of them, it was translated by Henry Bate at Orvieto and completed on October 28, 1292. ${ }^{26}$ (4) Liber causarum seu racionum super hiis que dicuntur in Introductorio Abrahe qui incipit Sapiencie timor domini (Book of causes or reasons on what has been said in the Introduction by Abraham, which begins the beginning of wisdom is the fear of the Lord') is the Latin of the first version of Sefer ha-Te 'amim (Book of reasons; henceforth Te 'amim I), Ibn Ezra's close commentary on Reshit Hokhmah. ${ }^{27}$ This translation, extant in two manuscripts, ${ }^{28}$ was carried out at Orvieto in $1292 .{ }^{29} \mathrm{It}$ begins with a translation of the initial canticle (a customary feature of Ibn Ezra's Hebrew astrological treatises) $)^{30}$ and concludes with an epilogue by the translator. ${ }^{31}$ (5) Liber causarum seu racionum (Book of causes or reasons), the Latin translation of the second version of Sefer ha-Te 'amim (Book of reasons; henceforth Te 'amim II), which is a commentary on the second version of Reshit Hokhmah. ${ }^{32}$ This Latin translation, too, extant in two manuscripts, ${ }^{33}$ was executed at Orvieto in $1292 .{ }^{34}$

Finally, at an unspecified date and place, Henry Bate composed a work of his own writing entitled De diebus creticis, which is not the same as his Latin translation of Ibn Ezra's Me 'orot, also exclusively concerned with the critical days. In this work Henry Bate made reference to Ibn Ezra and a number of his astrological works, including Me' orot..$^{35}$

Note that there is a wide mismatch between the Ibn Ezra works translated by Hagin le Juif and those translated or used by Henry Bate. First, only one (Reshit

26 Leipzig Univ. 1466, fols. 37r-49v; cf. Wallerand, Henri Bate, 17; Thorndike, 'The Latin translations', 296 (a \& b). The colophon is in Leipzig Univ. 1466, fol. 49v1.

27 References to Te amim I, which is extant in at least 32 manuscript copies, are in the format: Te ' amim I, ed. Sela, \$3.2:1, pp. 70-71 = first version of Sefer ha-Te' amim, chapter 3, section 2, passage 1, in The Book of Reasons, A Parallel Hebrew-English Critical Edition of the Two Versions of the Text, Edited, translated, and annotated by Shlomo Sela, Leiden: Brill, 2007, pp. 70-71.

28 Leipzig Univ. 1466, fols. 60v2-73v1; MS Limoges 9(28), fols. 1-44.

29 Leipzig Univ. 1466, fol. 73v1; cf. Wallerand, Henri Bate, 17; Thorndike, 'The Latin Translations', p. 297.

30 Leipzig Univ. 1466, fol. 60v2: 'Excelsus dominus et metuendus adaperiat et illuminet oculos nostros in libro rationum et dirigat gressus nostros in via veritatis' = 'May the exalted and feared Lord, open and enlighten our eyes in the Book of reasons, and lead our steps in the way of truth'.

31 Leipzig Univ. 1466, fol. 73v1 4-23.

32 References to Te ' amim II, which is extant in at least 25 manuscript copies, are in the format: Țe ' amim II, ed. Sela, §3.2:1, pp. 223-24 = second version of Sefer ha-Te ' amim, ed. Sela, chapter 3, section 2, passage 1, in The Book of Reasons, ed. Sela, pp. 223-24.

33 Leipzig Univ. 1466, fols. 49v2-60v2; MS Limoges 9(28), fols. 1-44.

34 Leipzig Univ. 1466, fol. 60v2; cf. Thorndike, 'The Latin Translations', p. 297.

35 See Giuseppe Dell'Anna, Dies critici: La teoria della ciclicità delle patologie nel XIV secolo, Galatina: Mario Congedo Editore, 1999, vol. 2, pp. 97-127. 
Hokhmah) of the six treatises translated by Henry Bate in 1281 and 1293 has a counterpart among the four translated by Hagin le Juif, which means that five of Bate's Latin translations ('Olam I, TTe 'amim I, Te 'amim II, Me'orot, and Mishpeței haMazzalot) do not seem to have been based on Hagin's Old French. Second, eight of the twelve works by Ibn Ezra from which Henry Bate paraphrased and translated short passages and embedded them in Nativitas are not among those translated by Hagin le Juif, which means that Bate had another source for them.

Hagin le Juif's Old French translations are not a terra ignota. They have been studied; one has even been published in a critical edition by Raphael Levy. ${ }^{36}$ Hence it is highly improbable (although not impossible) that additional old French translations by him remain to be discovered. As for the Ibn Ezra treatises used by Henry Bate that do not correspond to Hagin's Old French translations, it cannot be ruled out that Henry Bate read them by means of translations à quatre mains, and no old French translation was written down. Such a scenario is more plausible for Bate's translations of entire treatises than for the many short passages he embedded in Nativitas. Be that as it may, Henry Bate never acknowledges that he relied on Old French translations for his Latin versions, unlike Peter d'Abano, who openly admits following that method. ${ }^{37}$

By contrast, it is noteworthy that according to the colophon of De mundo vel seculo, Henry Bate's translation of 'Olam I, the translation was made de hebreo in latinum..$^{38}$ Also indicative of Henry Bate's modus operandi as a translator is that his translation of al-Kindī's Liber de iudiciis reuolutionum annorum mundi, made in Malines in 1278, according to the colophon, was carried out ex Habrayco in latinum..$^{39}$ Moreover, in a gloss added by the translator himself to De mundo vel

36 The Beginning of Wisdom, An Astrological Treatise by Abraham Ibn Ezra, ed. Raphael Levy and Francisco Cantera, Baltimore: The Johns Hopkins University Press, 1939, pp. 31-125.

37 Abrahe Avenaris Iudei Astrologi peritissimi in re iudiciali opera, Venice: Petrus Liechtenstein, 1507, sig. XXXIv. Henry Bate's and Peter d'Abano's Latin translations of Ibn Ezra's astrological treatises are virtually the same (except for d'Abano's translation of Moladot), and they were carried out almost simultaneously. This attests to the great popularity that Ibn Ezra's astrological treatises achieved in the last decade of the thirteenth century, but also indicates that Henry Bate's and Peter d'Abano's translation projects were fairly disconnected one from the other.

38 Oxford, Bodleian, Digby 212, fol. 52v2; cf. Abrahe Avenaris Iudei Astrologi peritissimi in re iudiciali opera (Venice: Petrus Liechtenstein, 1507), sig. LXXXV, both according to the printed editions and the manuscript copies.

39 MS Vatican, Palat. lat. 1377, fols. 55r-62r, esp. fol. 62r: 'Explicit liber de iudiciis reuolutionum annorum mundi quem compilauit Iacob filius Ysaac Alkindi. Expletus est libelus iste ascendente Cancro in quo luna coniuncta iam die tertia setembris anno domini $1278^{\circ}$ in Mechlinia. translatus ex Hebrayco in latinum per Henricum Bate'. I am grateful to David Juste for this datum. The Hebrew translation of this work is by now lost. Ibn Ezra mentions this work and quotes a fragment of it in 'Olam I but never acknowledges that he had translated it into Hebrew. See 'Olam I, ed. Sela, §44:1-6, pp. 82-83. 
The Ibn Ezra-Henry Bate Astrological Connection and the Three Abrahams

seculo, Henry Bate not only states explicitly that he had a Hebrew manuscript of 'Olam I in front of him, but also that the Hebrew script of part of it was illegible or its meaning unclear. ${ }^{40}$ Supporting evidence for the notion that Henry Bate could understand a Hebrew source text at least in part comes from the basic knowledge of Hebrew reflected in his work, particularly of astronomical terms related to the names of planets. ${ }^{41}$

Part Two

The Triple Abraham

The most intriguing and perplexing feature of the Henry Bate-Ibn Ezra astrological connection is that the former attributes the treatises that modern scholarship assigns to the latter to three different authors. All three are 'Abraham', but they are distinguished by their cognomens. One is Abraham Avenezra, the latinized form of Abraham Ibn Ezra; the second is Abraham Princeps, the Latin translation of the Hebrew name by which Abraham Bar Hiyya (ca. 1065ca. 1136) was known within Jewish society: Abraham ha-Naśi', i.e., Abraham the Prince; the third is Abraham Compilator, an otherwise unknown Latin name.

That Henry Bate thought he was dealing with three different Abrahams is corroborated by the following.

First, Henry Bate, in his Latin translations but particularly in his Nativitas, introduces them in the same passage. Sometimes he refers to all three in the same breath: 'uterque Abraham cum tertio vocato compilatore', that is, 'the two

40 Ibn Ezra opens 'Olam I with a lengthy, detailed and original mathematical explanation of the 120 planetary conjunctions, a numerical-cosmological pattern borrowed from pseudoPtolemy's Centiloquium. Henry Bate appears to have run into difficulty in the understanding of this section, for at the end of his translation of this section he added the following gloss: 'Inquit translator: hic est itaque sermo Auenesre secundum quod iacet in Ebraico, sed visum est nobis aut truncatam fuisse litteram in exemplari aut salvis bene dictis eius doctrinam nimis confusam tradidisse et minus artificiosam' = 'The translator said: so, this is Ibn Ezra's account according to what lies open in the Hebrew <text>, but it seems to me that either the written characters are truncated in the <manuscript> copy or, while the words are sound and well, its message has been transmitted in an exceedingly confused manner and with little skill'. See Leipzig Univ. 1466, fol. 25b1, lines 17-22.

41 In Nativitas, ed. Steel, lines 614-615, Henry Bate states that 'ab Hebreis vocatus est Mercurius stella solis', that is, 'Mercury is called by the Hebrews the star of the Sun', a statement attested to by the fact that Mercury is called in Hebrew כוכב חמה, lit. the star of the Sun. Another example is in Liber Introductionis ad Iudicia Astrologie, Leipzig Univ. 1466, fol. 43b2, lines 3-8), Henry Bate's translation of Mishpetei ha-Mazzalot: 'Clavis autem et sententia est quod est planeta veritatis et ideo vocatur est in hebrayco cedek idest iustus etiam et Saturnus eadem in hebrayco vocatus est Sabtay idest quiescens eo quod servit die sabati'. = 'As a rule, it is a planet of truth, therefore it was named Jupiter, in Hebrew ședek, meaning just, and Saturn is called so, in Hebrew shabbetai, meaning being at rest, because it is in charge of the Sabbat'. 
Abrahams together with a third one, called the Compiler';2 'Abraham Princeps et quidam Iudeus Abraham, non Auenezre, sed alter Compilator quidam', that is, 'Abraham the Prince, and a certain Jew <called> Abraham, <who is> not $<$ Abraham> Ibn Ezra, but another <Abraham>, the Compiler' ${ }^{43}$ In other cases, we find various combinations of two Abrahams, as in references to Abraham Avenezre and Abraham Compilator, ${ }^{44}$ Abraham Avenezre and Abraham Princeps, ${ }^{45}$ or a vague reference to two Abrahams indicated by the expression 'uterque Abraham', 'both Abrahams'. ${ }^{46}$

Second, when Henry Bate mentions any of the three Abrahams on his own, the name Abraham is usually accompanied by the name of an astrological treatise of which the relevant Abraham is taken to be the author. ${ }^{47}$ In many cases, these references are accompanied by passages that turn out to be translations, quotations, or paraphrases of excerpts from astrological treatises by Ibn Ezra. This allows us to establish which part of Ibn Ezra's corpus was associated with each Abraham. All in all, Nativitas incorporates at least 140 separate passages from twelve treatises by Abraham Ibn Ezra or attributed to him. There are also several references to 'Abraham Avenezre' and 'Abraham Princeps' in Henry Bate's complete Latin translations of Ibn Ezra's astrological writings. We now examine the references to each of the Abrahams separately.

\section{Abraham Avenezra}

Abraham Avenezra, the latinized form of Abraham Ibn Ezra, accounts for 84 of the 140 separate references in Nativitas, and for several references in Henry Bate's complete Latin translations of Ibn Ezra's astrological treatises; this makes him the most important of the three Abrahams as well as the name Henry Bate applied to the historical Abraham Ibn Ezra. A look at these references, the names of the treatises associated with 'Abraham Avenezra', and particularly the identification of the astrological treatise behind the passages associated with these references proves that Henry Bate excerpted these passages from eight of Ibn Ezra's astrological treatises. By contrast, he assigned only three works to 'Abraham Princeps' and one to 'Abraham Compilator'. With regard to the first group, the list below presents Bate's name for the treatise, the abbreviated

42 See Nativitas, ed. Steel, line 659.

43 See Nativitas, ed. Steel, lines 673-674, for other examples, see Nativitas, ed. Steel, lines 185-186, 812-817, 1682-1684.

$44 \quad$ Nativitas, ed. Steel, lines 329-333.

45 Nativitas, ed. Steel, lines 602-605. Latin translation of 'Olam I, Leipzig Univ. 1466, fol. 24r1, lines 13-17; fol. 24v1, lines 44-45; fol. 24v2, lines 1-5; quoted below in p. 8. Latin translation of Mishpetei ha-Mazzalot, Leipzig Univ. 1466, fol. 48r2, line 21; fol. 48v2, lines 5-6.

46 Nativitas, ed. Steel, lines 185, 817, 1140.

47 For examples, see next sections. 
Hebrew name of the treatise in Ibn Ezra's astrological corpus, and the number of references to this treatise in Henry Bate's Nativitas or Latin translations:

(1) Liber nativitatum $=$ Moladot, with 54 references in Henry Bate's Nativitas ${ }^{48}$ There are also references to this treatise by Abraham Avenezra in Henry Bate's prologue to his translations of 'Olam I and in his De diebus creticis. ${ }^{49}$

(2-3) Liber rationum $=$ TTe 'amim I and Țe 'amim II, with 24 references in the Nativitas, 10 to $\mathrm{Te}^{\mathrm{a}} \mathrm{amim} \mathrm{I}^{50}$ and 14 to Te amim II. ${ }^{51}$ In the prologue to Bate's complete translation of 'Olam I, Avenezra is referred to as the author of Te 'amim I. ${ }^{52}$ Although sometimes references to Te 'amim I can be distinguished from those to Te 'amim II only by matching the associated passage against the Hebrew texts of these two works ${ }^{53}$ on several occasions Te amim I is denominated Liber Rationum, prima parte or particula, ${ }^{54}$ that is, the first version of the Book of Reasons, while Te amim II is denominated Liber Rationum, secunda parte or particula. ${ }^{55}$ The same method of reference to Te 'amim I and Te 'amim II as Liber Rationum prima parte and secunda parte, occurs twice in Henry Bate's De diebus creticis. ${ }^{56}$

(4) Liber initium sapientiae $=$ Reshit Hokhmah, with 14 references in Henry Bate's Nativitas. ${ }^{57}$ Abraham Avenezra is made the author of Initium sapientiae not only in

48 For an example, see Nativitas, ed. Steel, lines 574-577: 'Dicit enim Avenezre ... in Libro Nativitatum: scito quod aspectus solis ad lunam siue sextilis siue trinus aut quartus melior est quam aspectus Iouis et Veneris. Quamuis enim ambe infortune coniuncte essent lune, fortitudo aspectus solis impedimenta repelleret ambarum'; cf. Moladot, ed. Sela, III vi 11, 4, pp. 154-155. For other examples, see Nativitas, ed. Steel, lines 88-91, 91-94, 103-104, 258-260, 328-331, 546$549,564-567,602-603,651-655,681-684,742-745,775-778$ et passim.

49 See Leipzig Univ. 1466, fol. 24r2, lines 15-18, cf. Moladot, ed. Sela, III v 4, 3, pp. 144-145; De diebus creticis, ed. Dell'Anna, p. 113, line 4, cf. Moladot, ed. Sela, III iv 11, 4, pp. 154-155.

50 See Nativitas, ed. Steel, lines 621-624; 768-769, 944-946, 1112-1116, 1637-1640, 1722-1723, $2160-$ $2162,2329-2333,2385-2387,84-85$ (versio altera).

51 See Nativitas, ed. Steel, lines 159-165, 593-595, 704-706, 853-854, 966, 1084-1087, 1089-1091, 1109-1110, 1280-1283, 1683-1686, 1961-1963, 2285-2286, 2380-2387, 2407-2409.

52 See Leipzig Univ. 1466, fol. 24r2, lines 9-10.

53 See, for example, Nativitas, ed. Steel, lines 704-706; cf. Țe amim II, ed. Sela, §8.7:4, pp. 254-255; Nativitas, ed. Steel, lines 853-854; cf. Țe 'amim II, ed. Sela, \$5.4:10, pp. 228-229.

54 Nativitas, ed. Steel, lines 620-624; cf. Te ‘ amim I, ed. Sela, §6.2:4, pp. 86-87; Nativitas, ed. Steel, lines 767-769; cf. Țe amim I, ed. Sela, §9.1:6, pp. 92-93; Leipzig Univ. 1466, fol. 24r2, lines 9-14, cf. Țe ' amim I, ed. Sela, §1.4:5, pp. 34-35; Nativitas, ed. Steel, lines 1112-1117; cf. Țe amim I, ed. Sela, §4.5:4-5, pp. 76-77.

55 Nativitas, ed. Steel, lines 159-160, 593.

56 See De diebus creticis, ed. Dell'Anna, p. 102, lines 20-21 and p. 125, line 9.

57 See, for example, Nativitas, ed. Steel, lines 615-619, cf. Reshit Hokhmah, ed. Sela, §7.4:8-9, pp. 198201. See also Nativitas, ed. Steel, lines 249-250, 699-701, 707-710, 821-825, 825-827, 827-829, 829-831, 869-876, 984-987, 1023-1026, 1349-1351, 2188-2190, 3001-3111. 
the colophon but also in the body text of Bate's complete Latin translation of Reshit Hokhmah. ${ }^{58}$

(5) Liber luminarium $=M e^{\prime}$ orot, with five references in the Nativitas ${ }^{59}$ and one reference in Henry Bate's De diebus creticis..$^{60}$ Abraham Ibn Ezra is mentioned as the author in the incipit of the manuscript copies as well as in the incipit and colophon of the printed edition of Henry Bate's Latin translation of this work. ${ }^{61}$

(6) Liber revolutionum annorum mundi or Liber coniunctionum or Tractatus Avenesre de planetarum Coniunctionibus et annorum revolutionibus mundanorum = 'Olam I, with three references in the Nativitas. ${ }^{62}$ There are no fewer than 16 references to Abraham Avenezra as the author of the book in the prologue to Bate's Latin translation of 'Olam I. ${ }^{63}$

(7) Liber interrogationum $=$ She elot II, with four references in the Nativitas. ${ }^{64}$ In one instance, Henry Bate mentions Avenezra in suo Libro interrogationum, i.e., Ibn Ezra in his Book of Interrogations. ${ }^{65}$ Henry Bate does so because he also assigns a Liber interrogationum to Abraham Princeps, as we shall see, and he wishes to draw a distinction between the two Abrahams.

(8) Liber electionum $=$ Mivharim II, with two references in the Nativitas ${ }^{66}$ and one reference in Henry Bate's De diebus creticis. ${ }^{67}$ In one instance, Bate mentions Avenezra in suo Libro electionum, i.e., Ibn Ezra in his Book of Elections. ${ }^{68}$ As with the Liber interrogationum, this is because Bate also attributes a Liber electionum to Abraham Princeps.

58 Leipzig Univ. 1466, fol. 2r1, lines 1-2; fol. 17r1, line 6.

59 See Nativitas, ed. Steel, lines 2987-2981, 3019-3022, 3119-3121, 3131-3132, 3137-3140.

60 See De diebus creticis, ed. Dell'Anna, p. 106, lines 15-17; cf. Me' orot, ed. Sela, §4:2-3, pp. 456-457.

${ }_{61}$ See Leipzig Univ. 1466, fol. 30v1, line 28; Abraham ibn Ezra: De luminaribus et diebus criticis (Padua: Matthaeus Cerdonis, 7 Feb. 1482/83), first and last pages.

62 See, for example, Nativitas, ed. Steel, lines 2049-2051; cf. 'Olam I, ed. Sela, §22:1, pp. 66-67. See also Nativitas, ed. Steel, lines 233-235, 380-382.

63 See Leipzig Univ. 1466, fol. 24r1, lines 1-3.

64 See Nativitas, ed. Steel, lines 604-605, 903-905, 1104-1107, 1910-1914.

65 See Nativitas, ed. Steel, lines 904-905; cf. She elot II, ed. Sela, §7.1:4, pp. 368-369.

66 See Nativitas, ed. Steel, lines 562-563, 605-607.

67 See De diebus creticis, ed. Dell'Anna, p. 113, line 3; cf. Mivharim II, ed. Sela, §1.5:3, pp. 152-153.

68 See Nativitas, ed. Steel, line 562; cf. Mivharim II, ed. Sela, §1.5:3, pp. 152-153. 
The Ibn Ezra-Henry Bate Astrological Connection and the Three Abrahams

\section{Abraham Princeps}

Abraham Bar Hiiyya (ca. 1065-ca. 1136), who vanished from the scene just before Abraham Ibn Ezra began his literary career, was known to medieval Jewish society as Abraham ha-Naśi', Abraham the Prince. In his Hebrew oeuvre, Ibn Ezra mentions Abraham Bar Hiyya a number of times, sometimes scornfully, but always adding the appellative ha-Naśi to his name. ${ }^{69}$ It is therefore understandable that Henry Bate might have thought that Abraham Princeps was the historical figure known to us as Abraham Bar Hiyya. It is quite surprising, though, that Bate believed that Abraham Princeps was Abraham Ibn Ezra's master and that Ibn Ezra himself admitted as much. This emerges from the following statement by Henry Bate in the prologue to his Latin translation of 'Olam I:

'Insuper et Abraham princeps quem Avenesre magistrum suum profitetur in $5^{\circ}$ Redemptionis Israel loquens de mutatione regnorum, de preliis, de fame et siccitate, leuitate et gravitate bladi sic ait: et hoc totum sciemus per revolutionem coniunctionis Saturni et Iovis idest sole intrante in Arietem, et caetera. ${ }^{70}$

Bar Hiyya, like Ibn Ezra, followed the Greco-Arabic scientific tradition and wrote on astronomy and astrology in Hebrew. He composed the first-ever Hebrew astronomical tables, known as Luhot ha-naśi (The Tables of the Prince), ${ }^{71}$ and Hešbon mahalakhot ha-kokhavim (Calculation of the stellar motions), which are the canons of the Tables). ${ }^{72}$ The last three chapters of Hešbon mahalakhot ha-kokhavim are devoted to mathematical astrology $;^{73}$ a monograph on anniversary horoscopy, probably composed by Bar Hiyya himself, is embedded in the Tables of the

69 See Sefer Ha'ibbur, A Treatise on the Calendar by Rabbi Abraham Ibn Ezra, trans. and annot. Mordechai S. Goodman, Jerusalem: Ktav, 2011, Hebrew part, p. 36, English part, pp. 66-67; long commentary on Daniel 11:31; Țe amim I, ed. Sela, 10.3:6, pp. 98-99, 10.4:3, pp. 98-99.

70 'In addition, Abraham Princeps, who Ibn Ezra admits is his master, in the fifth chapter <of the book> on the Redemption of Israel, speaks about the changing of the kingdoms, wars, famine, drought, low and high prices of the grain, and he says: all this we know by the revolution of the conjunction of Saturn and Jupiter, that is, when the Sun enters in Aries, etc'. See Leipzig Univ. 1466, fols. 24v1:44-45, 24v2:1-5. For an additional similar statement, see Leipzig Univ. 1466, fol. 24r1:13-17. That according to Henry Bate, Ibn Ezra considered Bar Hiyya to be his teacher, was already noticed, on the basis of Henry Bate's prologue to 'Olam I, by M. Steinschneider, 'Abraham Judaeus - Savasorda und Ibn Esra' in Gesammelte Schriften, Berlin: M. Poppelauer, 1925, p. 334, n. 6.

71 See, for example, Berlin OR. QU. 649, fols. 1r-79r.

72 José Maria Millás Vallicrosa, ed. and trans., La obra Séfer hesbón mahlekot ha-kokabim (Libro del cálculo de los movimientos de los astros) de R. Abraham bar Hiyya ha-Bargeloní, Madrid: CSIC, 1959.

73 La obra Séfer hesbón, ed. Millás Vallicrosa, Heb. sec., pp. 103-117. 
Prince.$^{74}$ Bar Hiyya wrote an epistle justifying the study and use of astrology; ${ }^{75}$ we also know that he planned to write a technical handbook on astrology. ${ }^{76}$ Bar Hiyya's most important astrological work is the fifth chapter of Megillat hamegalleh (Scroll of the revealer), which incorporates a Jewish and universal astrological history and an astrological prognostication of the coming of the Messiah, based on the interpretation of horoscopes cast at the vernal equinox of years in which conjunctions of Saturn and Jupiter took place. ${ }^{77}$ The Latin translation of the latter work, entitled Liber Abrahe Principis de Redemptione Israel, ${ }^{78}$ is the work by Abraham Princeps that Henry Bate mentions in the passage just quoted. ${ }^{79}$

Abraham Ibn Ezra uses the cognomen ha-Naśi', the Prince, in his two references to Abraham Bar Hiyya in Te amim I. Given that Henry Bate translated Te amim I into Latin, his renderings of these loci are germane for determining how the Abraham Princeps-Abraham Avenezre connection was shaped in Henry Bate's mind. In one reference, Henry Bate translates 'the aforementioned Prince', used by Ibn Ezra to refer to Abraham Bar Hiyya, as 'Princeps predictus' ${ }^{80}$ In the other place, Ibn Ezra writes that there is no need to expand on the astrological procedure of directions, 'because R. Abraham the Prince has mentioned them in his book'. In all the Hebrew manuscripts I examined, the name 'Abraham the

74 Shlomo Sela, 'A Newly Identified Essay on Anniversary Horoscopy Embedded in Abraham Bar Hiyya's Astronomical Tables: Hebrew Edition, Translation and Commentary', Aleph 13.1 (2013), pp. 27-76.

75 Zechariah Schwarz, ed., 'Abraham bar Hiyya, ' Iggeret R. Abraham b. Hiyya ha-Naśi' še-katav leR. Yehudah b. R. Barzillai', in S. Kraus, ed., Festschrift Adolf Schwarz zum siebzigsten Geburtstag, Berlin - Vienna: R. R. Löwit, 1917, Heb. section, pp. 33-36.

76 In the introduction to Bar Hiyya's Șurat ha-' areș (Form of the Earth) we read that this astrological textbook was intended to be the last part of a trilogy dealing with astronomy and astrology, although there is no evidence that Bar Hiyya ever wrote it. See Abraham Bar Hiyya, Tzurat Haaretz, ed. Raphael Lasri, Jerusalem: Hamachon Letchuna Vekidush Hachodesh, 2009, p. 39.

77 Adolf Poznanski and J. Guttmann, Abraham Bar Hiyya, Sefer Megillat ha-megalleh, Jerusalem: [s.n.], 1968, pp. 111-155.

78 See Wolfenbüttel, lat. 479, fol. 177. From the colophon (Wolfenbüttel, lat. 479, fol. 183; Leipzig Univ. 1467, fol. 227r1) we learn that this translation was carried out by the Dominican Theodericus de Northem, a baccalarius theologiae, from a previous Hebrew to Old French translation. See Otto von Heinemann, Die Handschriften der herzoglichen Bibliothek zu Wolfenbüttel, Wolfenbüttel, 1884, vol. I, p. 384, item 31. This Old French translation, too, was somewhat associated with Hagin le Juif. See Graziella Federici Vescovini, 'Una versione latina medievale dell'opera escatologica di Abramo bar Hijja (Savasarda) "Megillat ha-Megalleh": il "Liber de redemptione Israhel"', in E. Garin, ed., Filosofia e cultura, Rome: Editori e Riuniti, 1991, pp. 5-37, esp. p. 6-7.

79 For the Hebrew text behind this quote, see Megillat ha-megalleh, ed. Adolf Poznanski and J. Guttmann, p. 116, lines 1-9.

80 See Leipzig Univ. 1466, fol. 72r1, lines 19-20; cf. Țe ‘ amim I, §10.4:3, pp. 98-99. 
The Ibn Ezra-Henry Bate Astrological Connection and the Three Abrahams

Prince' is preceded by the abbreviation 'ר, which stands for 'Rabbi'. In this context, the honorific means 'teacher', and not necessarily Jewish religious leader, which Ibn Ezra was not. Henry Bate, in turn, correctly translated this passage as 'Magister Abraham, vocatur Princeps, in libro suo'; i.e., 'Master Abraham, called the Prince, in his book'. ${ }^{81}$ But why did Henry Bate, in the prologue to his Latin translation of 'Olam I (twice) ) $^{82}$ and in his Nativitas (also twice), ${ }^{83}$ jump to the conclusion that Abraham Ibn Ezra himself admitted that Abraham the Prince was his master?

The answer is Henry Bate's peculiar reading of passages in Te amim I where Ibn Ezra refers to himself. Ibn Ezra had the immodest habit, particularly in his astrological treatises, of inserting his name, Abraham, to indicate that he was the originator of some idea. As a rule, he used the expression 'I Abraham', in the first person. However (probably due to posthumous interpolations by scribes and disciples) from time to time the name Abraham, as the originator of some idea, also occurs in the third person. Moreover, a number of Hebrew manuscripts offer the reading רבינו אברהם אמר, that is, 'Our Master Abraham, said. ...' Four of these instances occur in Te 'amim I. Henry Bate, in his Latin translation of Te 'amim I, took them at face value and read them as Ibn Ezra's references to his master, Abraham the Prince. In the first of them, he translated 'dicit magister noster Abraham, vocatus Princeps ...'-'Our Master Abraham, called the Prince, said. .... ${ }^{84}$ In the other three passages he wrote 'dicit/ait/inquit magister noster Abraham''Our Master Abraham, said. ... ${ }^{85}$

Henry Bate assigns four treatises to Abraham Princeps. One is the aforementioned Liber redemptionis Israel, which, of all the treatises he assigned to one of the three Abrahams, is the only one not composed by Ibn Ezra. Liber redemptionis Israel is assigned to Abraham Princeps twice in the prologue to the Latin translation of 'Olam I; in both instances the reference is accompanied by a

81 See Leipzig Univ. 1466, fol. 72r1, lines 11-14; cf. Țe amim I, \$10.3:6, pp. 98-99: אברהם הנשיא בספרו. Here 'his book' is a reference to chapter 20 of the aforementioned Hešbon mahalakhot hakokhavim, where Bar Hiyya deals with the directions. See La obra Séfer hesbón, ed. Millás Vallicrosa, Hebrew part, pp. 112-117.

82 See above.

83 Nativitas, ed. Steel, lines 119, 1683-1684.

84 See Oxford, Bodleian Library, Add. Qu. 160, fol. 74b, line 17; cf. Leipzig Univ. 1466, fol. 66r1, line 38; Te amim I, §3.4:8, pp. 62-63.

85 See (1) Oxford, Bodleian Library, Add. Qu. 160, fol. 75b, line 1; cf. Leipzig Univ. 1466, fol. 66b1, line 8; Te 'amim I, §3.6:1, pp. 66-67. (2) Oxford, Bodleian Library, Add. Qu. 160, fol. 76b, lines 7-8; cf. Leipzig Univ. 1466, fol. 67a1, line 24; Țe amim I, §4.1:1, pp. 68-69. (3) See Oxford, Bodleian Library, Add. Qu. 160, fol. 83b, line 26; cf. Leipzig Univ. 1466, fol. 71b1, line 37; Te 'amim I, §10.1:1, pp. 94-95. 
quotation, whose counterpart may be found in Bar Hiyya's Megillat ha-megalleh. ${ }^{86}$ The same treatise is assigned again to Abraham Princeps in the Nativitas, where Bar Hiyya's work is called Tractatus coniunctionum, the Book of the Conjunctions, ${ }^{87}$ a name that reflects the historical analysis in this work based on examination of the Saturn-Jupiter conjunctions. That this is indeed a reference to the fifth chapter of Megillat ha-megalleh is supported by the fact that the quotations accompanying the reference in Henry Bate's Nativitas and in one of the passages of the prologue to Henry Bate's Latin translation of 'Olam I are virtually the same. ${ }^{88}$

Abraham Ibn Ezra is the author of the other three treatises Bate attributed to Abraham Princeps. One is Mishpetei ha-Mazzalot, translated into Latin by Henry Bate in $1292 .{ }^{89}$ In a title at the beginning of the translation we read: 'Ysagoge magistri Abrahe Ducis seu Principis notati hebrayce Nati Hezkia' ${ }^{90}=$ 'Introduction by Master Abraham, the Commander or the Prince, known in Hebrew as Bar Hiyya'. This is the only instance in Henry Bate's entire work where Abraham Bar Hiyya appears as the author of one of the astrological treatises Bate translated or referred to. The synonymous names Abraham Dux and Abraham Princeps occur several times in glosses and in an epilogue added by Henry Bate to his translation of Mishpetei ha-Mazzalot, ostensibly as references to the name of the author of the translated work. ${ }^{91}$ In addition, in an epilogue Bate added to his Latin translation of Te'amim I, we find a reference to 'Introductorius Abrahe Ducis capitulo de aspectibus', ${ }^{92}$ i.e., 'the chapter on the aspects in the introduction by Abraham Dux'. This is a cross-reference that Bate inserted to his translation of the section on the aspects at the end of Mishpetei ha-Mazzalot. ${ }^{93}$ There is also one reference to a passage of Mishpetei ha-Mazzalot in the Nativitas. ${ }^{94}$

86 For the first reference and quotation, see Leipzig Univ. 1466, fol. 24r1, lines 13-17, cf. Megillat ha-megalleh, ed. Adolf Poznanski and J. Guttmann, p. 117, lines 16-19. For the second reference and quotation, see Leipzig Univ. 1466, fol. 24v1, lines 44-45; fol. 24v2, lines 1-5; cf. Megillat hamegalleh, ed. Adolf Poznanski and J. Guttmann, p. 116, lines 1-9.

87 Nativitas, ed. Steel, lines 2354-2356. Note that in an additional copy of the fifth chapter of the Latin translation of Bar Hiyya's Megillat ha-megalleh, the latter work is entitled Abraham de coniunctionibus magnis. See Leipzig Univ. 1467, fol. 214 r1.

88 Leipzig Univ. 1466, fol. 24r1, lines 10-14: 'secundum motus medios ... prout apparet ex uerbis Abrahe principis in 5. particula Libri Redemptionis Israel'. cf. Nativitas, ed. Steel, lines 23542358: 'Iupiter et Saturnus in eodem gradu coniunctionis sunt secundum medios motus ipsorum prout testatur Hispanus Abraham cognomine Princeps in suo tractatu Coniunctionum'.

89 See above, p. 4.

90 See Leipzig Univ. 1466, fol. 27r2, lines 1-2.

91 See Leipzig Univ. 1466, fols. 48v2, lines 5-6; fol. 48v2, line 30; fol. 49r1, line 13; fol. 49r2, line 45; fol. 49v1, line 5.

92 See Leipzig Univ. 1466, fol. 73v1, lines 17-18.

93 See Leipzig Univ. 1466, fols. 47r2, line 12 through 48r1, line 18; cf. Mishpetei ha-Mazzalot, ed. Sela, §71:1-7 through §75:1-7, pp. 550-555. 
The Ibn Ezra-Henry Bate Astrological Connection and the Three Abrahams

The other two treatises by Ibn Ezra that Bate assigned to Abraham Princeps are works whose Hebrew original is lost but that are extant in Latin translations. Henry Bate refers to them only in his Nativitas; it is noteworthy that the references are accompanied by translations or paraphrases that are not the same as the corresponding passages in the available Latin translations. ${ }^{95}$ The logical conclusion is that Henry Bate translated or paraphrased these passages directly from the lost Hebrew text or from an Old French translation.

(1) There are 21 references to Liber nativitatum (Book of the nativities), one of the treatises Bate assigned to Abraham Princeps, in the Nativitas. ${ }^{96}$ A scrutiny of the translations or paraphrases accompanying these references demonstrates that this Nativitatum is identical with Ibn Ezra's second version of Sefer ha-Moladot (henceforth Moladot II). ${ }^{97}$ Henry Bate appears to be familiar with this work, because, besides the frequent references to it, he mentions 'its beginning', 'the chapter of the testimonies', and 'the chapter on the seventh horoscopical place'. ${ }^{98}$

(2) Bate's Nativitas also assigns (twice) a work on the doctrine of elections to Abraham Princeps, under two slightly different names. One is Tractatus de electionibus, with a passage on the trutina Hermetis or 'balance of Hermes', a procedure used in the doctrine of nativities to determine the ascendant of the natal horoscope when the time of birth is not known (the usual situation). The trutina Hermetis is referred to in Ibn Ezra's works on nativities as well as in his introductions to astrology. ${ }^{99}$ The only exception is the third version of Ibn Ezra's Sefer ha-Mivharim (Book of Elections; henceforth Mivharim III), ${ }^{100}$ which includes a

94 Nativitas, ed. Steel, lines 694-697; cf. Mishpeței ha-Mazzalot, ed. Sela, §29:1, pp. 512-513.

95 See, for example, note 97.

96 See Nativitas, ed. Steel, lines 602-603, 655-676, 682-684, 735-736, 812-814, 1054-1057, 1196-1200, 1584-1586, 1595-1596, 1684-1686, 1737-1740, 1759-1760, 1774-1776, 1787-1788, 2249-2251, 2236-2237, 2237-2239, 2650-2652, 2662-2664, 2765-2767.

97 The Hebrew original of Moladot II is lost but survives today in a Latin translation, available in two manuscript copies and entitled Liber nativitatum. See Erfurt, Amplon, MS 0.89, fols. 53a-68b; Vienna, Österreichische Nationalbibliothek, MS 5442, fols. 203b-217b. See, for example, Nativitas, ed. Steel, lines 2648-2652: '... secundum testimonium Abrahe Principis. Item dicit idem Princeps quod cum dominus octave domus fuerit in opposito ascendentis aut domini ejus secundum quod hic se habent luna et sol significant hec quod natus cadet ab alto et morietur'; cf. Liber nativitatum, Erfurt, Amplon, 0.89, fol. 66a lines 21-23: 'Et si fuerit dominus octave in opposito domus prime aut in opposito grado domini ascendente aut in opposito loci potentis, cadet natus ex loco alto et morietur'.

98 See, respectively, Nativitas, ed. Steel, lines 681-682, 735-736, 1787-1788.

99 See Shlomo Sela, 'Abraham Ibn Ezra's Role in the Creation and Diffusion of the Trutina Hermetis', in C. Dopfel and A. Focati (eds.) Pregnancy and Childbirth from Late Antiquity to the Renaissance, Brepols, forthcoming.

100 A fragment of Mivharim III survives in a parchment bifolium in the Archivio di Stato, Modena, but its complete Latin translation, entitled Liber Eleccionum, is extant in two manuscript copies: 
detailed discussion of the trutina Hermetis, from which Bate excerpted the passage found in the Nativitas. ${ }^{101}$ In another passage, Nativitas refers jointly to Ibn Ezra and his master, Abraham Princeps, with regard to the trutina Hermetis. This is an implicit reference to Ibn Ezra's Moladot, which includes a detailed account of the trutina Hermetis, and to the aforementioned Tractatus de electionibus by Abraham Princeps. ${ }^{102}$ The second mention in the Nativitas of Abraham Princeps as the author of a work on the doctrine of elections is a reference to the chapter on the seventh horoscopic place in Liber electionum, whose counterpart may be found in Mivharim III. ${ }^{103}$ Bate's Nativitas also includes a third implicit reference to Mivharim III. ${ }^{104}$

\section{Abraham Compilator}

The most intriguing of the three Abrahams is Abraham Compilator, mentioned sixteen times in the Nativitas. ${ }^{105}$ In one of these Abraham Compilator is referred to as 'Iudeus', a Jew; ${ }^{106}$ and in two other loci the name 'Abraham Iudeus' appears alone. ${ }^{107}$ The latter designation is also found once in Bate's philosophical encyclopedia, Speculum divinorum et quorundam naturalium..$^{108}$ A close look at this passage that the Speculum divinorum assigns to Abraham Iudeus reveals that it is a verbatim quotation from a Latin astronomical work known today as Liber de rationibus tabularum (Book of the reasons of astronomical tables), which Henry Bate calls Liber de opere tabularum (Book on the use of <astronomical> tables). This work, which is extant in six manuscript, two of them from the end of the twelfth

MS Erfurt, Amplon, MS 0.89, fols. 39b-46b; MS Vienna, Österreichische Nationalbibliothek, MS 5442, fols. 192b-198b. References to Mivharim III are in the format: Liber Eleccionum, MS Erfurt, fol. 42a, lines 6-14.

101 See Nativitas, ed. Steel, lines 106-117; cf. Liber Eleccionum, Erfurt, fol. 42a, lines 6-14. This passage is analyzed in Sela, 'Abraham Ibn Ezra's Role in the Creation and Diffusion of the Trutina Hermetis', forthcoming.

102 Nativitas, ed. Steel, lines 118-119: 'Hee sunt equationes annimodar Hermetis quas ponunt Auenezre et magister suus Princeps Abraham'. For the account of the trutina Hermetis in Sefer ha-Moladot, see Moladot, ed. Sela, II 5, 1-10, II 6, 1-6, pp. 92-95.

103 See Nativitas, ed. Steel, lines 603-604; cf. Liber Eleccionum, Erfurt 0.89, fol. 45a, lines 9-13.

104 See Nativitas, ed. Steel, lines 1919-1920; cf. Liber Eleccionum, Erfurt 0.89, fols. 44b, line 31-45a, line 1.

105 See Nativitas, ed. Steel, lines 332, 659, 674, 713, 1146, 1273, 1533, 1543, 1682, 2175, 2287, 2449, $2494,2645,2688,3340$.

106 Nativitas, ed. Steel, lines 712-713: 'dicit Iudeus ille Abraham Compilator'.

107 Nativitas, ed. Steel, lines 178; 712-713.

108 Henricus Bate, Speculum Divinorum et Quorundam Naturalium, Parts XX-XXIII: ed. Carlos Steel and Guy Guldentops, Leuven: Leuven University Press, 1996, p. 337. 
century, is a Latin version of the canons of Ibn Ezra's astronomical tables, whose Hebrew original is now lost. ${ }^{109}$

That Bate held Abraham Compilator and Abraham Iudeus to be the same person is proven by the fact that he assigns one work, Liber nativitatum (Book of Nativities), to both of them. ${ }^{110}$ All the 18 passages from Liber Nativitatum that Henry Bate's Nativitas assigns to Abraham Compilator or Abraham Iudeus ${ }^{111}$ were excerpted from Liber Abraham Iudei de nativitatibus (henceforth De nativitatibus), a Latin astrological treatise on nativities traditionally assigned to Ibn Ezra. ${ }^{112}$ Here it is noteworthy that 10 of these 18 passages are verbatim quotations from De nativitatibus ${ }^{113}$ which proves that Henry Bate had a copy of De nativitatibus in his library. As noted above, Henry Bate incorporated astrological material he culled from 12 astrological treatises written by or attributed to Abraham Ibn Ezra into his Nativitas. De nativitatibus is the only one from which Henry Bate excerpted verbatim quotations corresponding to the extant text of this Latin treatise in manuscripts or print editions. These ten verbatim quotations are the earliest evidence of the existence of De nativitatibus. Whereas all the incipits and explicits of the manuscript and print editions of De nativitatibus make Abraham Iudeus its

109 See Millás Vallicrosa, El Libro de los Fundamentos, esp. pp. 11-70; Shlomo Sela, Abraham Ibn Ezra and the Rise of Medieval Hebrew Science, Leiden: Brill Academic Publishers, 2003, pp. 22-27.

110 See Nativitas, ed. Steel, lines 332-333, 177-178, et passim.

111 See Nativitas, ed. Steel, lines 177-178, 332-333, 578-80, 655-659, 674-677, 712-715, 1146-1148, 1270-1273, 1538-1540, 1542-1545, 1681-1683, 2174-2175, 2287, 2439-2441, 2491-2494, 26452649, 2688-2691, 3340-342.

112 Abraham Iudei de nativitatibus, Venice: Erhard Ratdolt, 1485, sig. a2r-crv. This text bears striking resemblances to the two versions of Moladot and to other parts of Ibn Ezra's oeuvre, but the nature of its affiliation with Ibn Ezra is unclear: is De nativitatibus the translation of a lost Hebrew text by Ibn Ezra, a later elaboration based on Latin translations of carefully selected fragments from Ibn Ezra's Hebrew astrological treatises, or a Latin treatise of nativities composed with Ibn Ezra's active participation? I hope to address this question in a separate study in the near future, and to publish a critical edition and a study of this text. For previous references to the connection between De nativitatibus and Ibn Ezra, see Moritz Steinschneider, 'Abraham Ibn Esra (Abraham Judaeus, Avenare)', Supplement zur Zeitschrift für Mathematik und Physik, 25 (1880): 59-128 (=Gesammelte Schriften, [Berlin 1925], 407-498), p. 497; Thorndike, 'The Latin Translations', pp. 297-298; Millás Vallicrosa, El Libro de los Fundamentos, pp. 16, 20; Renate Smithuis, Abraham ibn Ezra the Astrologer and the Transmission of Arabic Science to the Christian West, doctoral dissertation, University of Manchester, 2004, chapter 4.

113 Nativitas, ed. Steel, lines 178-183; cf. De nativitatibus, ed. Ratdolt, sig. a2v:21-25; Nativitas, ed. Steel, lines 578-580, cf. De nativitatibus, ed. Ratdolt, sig. a7v:14-15; Nativitas, ed. Steel, lines 11461148, cf. De nativitatibus, ed. Ratdolt, sig. a6r:8-11; Nativitas, ed. Steel, lines 712-715, cf. De nativitatibus, ed. Ratdolt, sig. a8r:12-14; Nativitas, ed. Steel, lines 1542-1545, cf. De nativitatibus, ed. Ratdolt, sig. b4r: 17-20; Nativitas, ed. Steel, lines 1538-1540, cf. De nativitatibus, ed. Ratdolt, sig. b6v: 33-35; Nativitas, ed. Steel, lines 1681-1683, cf. De nativitatibus, ed. Ratdolt, sig. b2v: 1314; Nativitas, ed. Steel, lines 2174-2175, cf. De nativitatibus, ed. Ratdolt, sig. c1v:22; Nativitas, ed. Steel, lines 2439-2441, cf. De nativitatibus, ed. Ratdolt, sig. c3r: 6-8; Nativitas, ed. Steel, lines 26882691, cf. De nativitatibus, ed. Ratdolt, sig. b8v:14-17. 
author, at least one manuscript gives the author as both Abraham Iudeus and Abraham Compilator. ${ }^{114}$ This explains why Henry Bate called the third Abraham both Abraham Iudeus and Abraham Compilator and why he assigned De nativitatibus to both.

\section{Conclusion}

Finally, let us ask: Why did Henry Bate split Abraham Ibn Ezra into three Abrahams and divide Ibn Ezra's astrological oeuvre among them? I would suggest that Bate 'invented' the three Abrahams principally to accommodate the fact that in his Nativitas he was working with three different treatises called Liber nativitatum, each written by a Jew whose name was Abraham. Henry Bate did not know that a main feature of Ibn Ezra's modus operandi was the production of two or more versions or recensions of each treatise. Because Henry Bate was drawing on three Hebrew treatises in the same branch of astrological literature, nativities, and because he found it odd that they were all written by the same person, the best solution he could find was to attribute each of the three to a different Abraham. ${ }^{115}$

One of them is the Liber nativitatum that Henry Bate certainly knew was written by Abraham Avenezra, because he became acquainted with it in 1273, via the Old French translation by Hagin le Juif. He assigned seven other astrological treatises to the same Abraham Avenezra, knowing for certain that he was the author, probably because he found them all in the same manuscript or because he became familiar with them through the same informant, Hagin le Juif.

It seems likely that Henry Bate assigned the second Liber nativitatum to Abraham Princeps because he discovered it not through Hagin le Juif's translations but from another Hebrew manuscript source or another informant. It was thanks to the same alternative Hebrew manuscript or informant that Bate encountered Ibn Ezra's Mishpetei ha-Mazzalot and the third version of Sefer haMivharim. Since he knew that these works were close in style and essence to those

114 See Oxford, Bodleian Library, Bodley 472, fol. 144r: 'Abraham Iudeus de nativitatibus, qui Compilator dicitur'.

115 Note that from among a total of 140 references to the three Abrahams, 54 references are to Liber Nativitatum by Abraham Avenezra, 21 references are to Liber Nativitatum by Abraham Princeps, and 18 references are to Liber Nativitatum by Abraham Compilator. Another relevant case relates to Initium Sapientiae, the Latin translation of Ibn Ezra's Reshit Hokhmah, assigned by Henry Bate to Abraham Avenezra, on the one hand, and to Introductorius ad Iudicia Astrologiae, assigned by Henry Bate to Abraham Princeps, on the one other. Both are introductions to astrology. The Latin Translations of Te amim I and Te amim II are not a relevant case because Henry Bate considered them to be two parts of the same treatise: as seen above Henry Bate calls both with the same name and distinguishes between them by calling T? 'amim I Liber Rationum, prima parte and Te ' amim II Liber Rationum, secunda parte. See above, p. 7. 
The Ibn Ezra-Henry Bate Astrological Connection and the Three Abrahams

by Abraham Avenezra, he assigned them to Abraham Princeps, whom he mistakenly took to be Abraham Avenezra's master, Abraham Bar Hiyya.

The third Liber nativitatum is identical with De nativitatibus, a Latin astrological treatise which bears striking resemblances to the two versions of Moladot and to other parts of Ibn Ezra's oeuvre, but is markedly different from any of them, its affiliation with Ibn Ezra remains unclear, and is extant in at least 15 manuscripts. ${ }^{116}$ As said above, the incipit of one of the manuscripts gives the author as both Abraham Iudeus and Abraham Compilator, which explains why Henry Bate called the third Abraham both Abraham Iudeus and Abraham Compilator and why he assigned De nativitatibus to both. ${ }^{117}$ The verbatim quotations from De nativitatibus in Henry Bate's Nativitas are the earliest evidence of the existence of De nativitatibus. An examination of the possibility that Henry Bate played some role in giving the final shape to De nativitatibus is left for a separate study.

\section{Bibliography}

Manuscripts

Berlin, Staatsbibliotek zu Berlin, MS 963, fols. 152-163r.

Leipzig University, MS 1466, fols. 2r-23v, 30v-34r, 37r-49v, 49v2-60v2, 60v2-73v1. Limoges, MS 9(28), fols. 66-71v.

Oxford, Bodleian Library, MS Bodley 472, fol. 144r1-155v2.

Oxford, Bodleian, MS Digby 212, fols. 48v1-52v2.

Paris, Bibliothèque nationale de France, fonds français, MS 24276, fols. 1a-66a.

Paris, Bibliothèque nationale de France, fonds français, MS 1351, fols. 1a-66a.

Prague, MS 433 (III.C.2), fol. 118v2-125r2.

Vatican, Palat. lat. 1377, fols. 21r-37v.

Wolfenbütel, MS 2816, fols. 84-111.

116 For a partial list of manuscripts, see Thorndike, 'The Latin Translations', pp. 297-298, 302. See above, note 112 .

117 See above, note 114 . 
Sources

A Medieval Autobiographical Horoscope: Henry Bate's Nativitas (1280), edited by Carlos Steel, annotated and introduced by Steven Vandenbroecke, with the collaboration of David Juste and Shlomo Sela, Leuven: Leuven University Press, 2017.

Abraham Bar Hiyya, Tzurat Haaretz, ed. Raphael Lasri, Jerusalem: Hamachon Letchuna Vekidush Hachodesh, 2009.

Abraham Ibn Ezra, De luminaribus et diebus criticis, Padua: Matthaeus Cerdonis, 7 Feb. 1482/83).

Abraham Iudei de nativitatibus, Venice: Erhard Ratdolt, 1485.

Abrahe Avenaris Iudei Astrologi peritissimi in re iudiciali opera, Venice: Petrus Liechtenstein, 1507.

Dell'Anna, Giuseppe, Dies critici: La teoria della ciclicità delle patologie nel XIV secolo, Galatina: Mario Congedo Editore, 1999.

Guidonis Bonati Forolviensis Mathematici de Astronomia Tractatus X, Basileae, 1550.

Lévy, Tony and Burnett, Charles, 'Sefer ha-Middot: A Mid-Twelfth-Century Text on Arithmetic and Geometry Attributed to Abraham ibn Ezra', Aleph 6 (2006): pp. 57-238.

Millás Vallicrosa, Jose $\mathrm{M}^{\mathrm{a}}$ (ed.), El Libro de los Fundamentos de las Tablas Astronómicas de R. Abraham Ibn Ezra, Madrid - Barcelona: CSIC, 1947.

Millás Vallicrosa, Jose $\mathrm{M}^{\mathrm{a}}$, 'Un nuevo tratado de astrolabio de R. Abraham ibn Ezra', Al-Andalus, 5 (1940), pp. 9-29.

Millás Vallicrosa, Jose $\mathrm{M}^{a}$, ed. and trans., La obra Séfer hesbón mahlekot ha-kokabim (Libro del cálculo de los movimientos de los astros) de R. Abraham bar Hiyya ha-Bargeloní, Madrid: CSIC, 1959.

Poznanski, Adolf, and J. Guttmann, Abraham Bar Hiyya, Sefer Megillat ha-megalleh, Jerusalem: [s.n.], 1968.

Schwarz, Zechariah (ed.), 'Abraham bar Ḥiyya, 'Iggeret R. Abraham b. Hiiyya haNaśi še-katav le-R. Yehudah b. R. Barzillai,' in S. Kraus (ed.), Festschrift Adolf Schwarz zum siebzigsten Geburtstag, Berlin and Vienna: R. R. Löwit, 1917, Heb. section, pp. 33-36.

Sefer Ha ibbur, A Treatise on the Calendar by Rabbi Abraham Ibn Ezra, trans. and annot. by Mordechai S. Goodman, Jerusalem: Ktav, 2011. 
The Ibn Ezra-Henry Bate Astrological Connection and the Three Abrahams

Sela, Shlomo, Abraham Ibn Ezra on Elections, Interrogations and Medical Astrology, A Parallel Hebrew English Critical Edition of the Book of Elections (3 Versions), the Book of Interrogations (3 versions) and the Book of the Luminaries, edited, translated and annotated by Shlomo Sela, Leiden: Brill, 2011.

Sela, Shlomo, Abraham Ibn Ezra's Introductions to Astrology, A Parallel Hebrew-English Critical Edition of the Book of the Beginning of Wisdom and the Book of the Judgments of the Zodiacal Signs, ed., trans., and annot. by Shlomo Sela, Leiden: Brill, 2017.

Sela, Shlomo, The Book of Reasons, A Parallel Hebrew-English Critical Edition of the Two Versions of the Text, edited, translated, and annotated by Shlomo Sela, LeidenBoston: Brill Academic Publishers, 2007.

Sela, Shlomo, The Book of the World, A Parallel Hebrew-English Critical Edition of the Two Versions of the Text, edited, translated, and annotated by Shlomo Sela, LeidenBoston: Brill Academic Publishers, 2010.

The Beginning of Wisdom, An Astrological Treatise by Abraham Ibn Ezra, ed. Raphael Levy and Francisco Cantera, Baltimore: The Johns Hopkins University Press, 1939.

Zambelli, Paola, The Speculum Astronomiae and Its Enigma, Dordrecht: Kluwer Academic Publishers, 1992.

\section{Secondary Literature}

Boudet, Jean-Patrice, Entre science et nigromance. Astrologie, divination et magie dans l'Occident médiéval (XIIe-XVe siècle), Paris: Publications de la Sorbonne, 2006.

Burnett, Charles, 'Béziers as an Astronomical Centre for Jews and Christians in the Mid-Twelfth Century,' Aleph, forthcoming.

Federici Vescovini, Graziella, 'Una versione latina medievale dell'opera escatologica di Abramo bar Hijja (Savasarda) Megillat ha-Megalleh: il Liber de redemptione Israhel', in E. Garin (ed.), Filosofia e cultura, Rome: Editori e Riuniti, 1991, pp. 5-37.

Grant, Edward, The Foundations of Modern Science in the Middle Ages, Cambridge: Cambridge University Press, 1996.

Hendrix, Scott, How Albert the Great's Speculum Astronomiae Was interpreted and Used by Four Centuries of Readers: A Study in Late Medieval Medicine, Astronomy and Astrology, Lewiston: The Edwin Mellen Press, 2010.

Juste, David, 'The Impact of Arabic Sources on European Astrology: Some Facts and Numbers', Micrologus XXIV (2016), pp. 173-194. 
Paravicini Bagliani, Agostino, Le 'Speculum Astronomiae,' une énigme? Enquête sur les manuscrits, Firenze: SISMEL Edizioni del Galluzzo, 2001.

Poulle, Emmanuelle, 'Henry Bate of Malines' in Dictionary of Scientific Biography, vol. VI, New York, 1972, pp. 272-275.

Sela, Shlomo and Freudenthal, Gad, 'Abraham Ibn Ezra's Scholarly Writings: A Chronological Listing', Aleph 6 (2006), pp. 13-55.

Sela, Shlomo, 'A Newly Identified Essay on Anniversary Horoscopy Embedded in Abraham Bar Hiyya's Astronomical Tables: Hebrew Edition, Translation and Commentary', Aleph 13.1 (2013), pp. 27-76.

Sela, Shlomo, 'Astrology in Medieval Jewish Thought' in G. Freudenthal (ed.), Science in Medieval Jewish Cultures, Cambridge: Cambridge University Press, 2012, pp. 296-299.

Sela, Shlomo, 'The Astrological-Astronomical Encyclopedia in MS Paris 1058', Aleph 14.1 (2014), pp. 189-241.

Sela, Shlomo, Abraham Ibn Ezra and the Rise of Medieval Hebrew Science, Leiden: Brill Academic Publishers, 2003.

Siraisi, Nancy G., Medieval \& Early Renaissance Medicine: An Introduction to Knowledge and Practice, Chicago and London: The University of Chicago Press, 1990.

Smithuis, Renate, 'Science in Normandy and England under the Angevins. The Creation of Avraham Ibn Ezra's Latin Works of Astronomy and Astrology', in G. Busi (ed.), Hebrew to Latin - Latin to Hebrew: The Mirroring of Two Cultures in the Age of Humanism, Berlin and Turin, 2006, pp. 26-61.

Smithuis, Renate, Abraham ibn Ezra the Astrologer and the Transmission of Arabic Science to the Christian West, doctoral dissertation, University of Manchester, 2004.

Steinschneider, Moritz, 'Abraham Judaeus Savasorda und Ibn Esra', in Gesammelte Schriften, Berlin: M. Poppelauer, 1925, pp. 327-387.

Thorndike, Lynn, 'The Latin translations of the astrological tracts of Abraham Avenezra', Isis 35 (1944), pp. 293-302.

Thorndike, Lynn, A History of Magic and Experimental Science, New York: Columbia University Press, 1923-1958.

Wallerand, Gaston, Henri Bate de Malines, Speculum Divinorum et Quorundam Naturalium, Louvain: Institut Supérieur de Philosophie de l'Université, 1931. 